\title{
Characterization of the Thermal Behavior of the Full Scale Testing Module, Using 17.5\% of Glazing with Different Orientations in Mexico City.
}

\author{
Ricardo Sánchez B. ${ }^{1}$, Sabarinah S. Ahmad ${ }^{2}$, Leonardo B. Zeevaert ${ }^{1}$ and Arturo Valeriano F ${ }^{1}$ \\ ${ }^{1}$ Master Program in Architecture, National Autonomous University of Mexico, Mexico City, Mexico. \\ ${ }^{2}$ Department of Architecture, Faculty of Architecture, Planning and Surveying, Universiti Teknologi MARA, Shah Alam 40450, Selangor, \\ Malaysia \\ *Corresponding author E-mail: sanchezrick99@comunidad.unam.mx
}

\begin{abstract}
The study aims to understand the thermal performance behavior of a double skin envelope system in a test cell. A rooftop observation deck and experimentation laboratory is installed at the " $\mathrm{J}$ " Building of the Postgraduate Unit, National Autonomous University of Mexico campus $\left(19^{\circ} 18^{\prime} 33.59^{\prime} \mathrm{N}, 99^{\circ} 11^{\prime} 5.73\right.$ ”O). This platform consists of two full-scale testing modules. Each cubic module measures $3 \mathrm{~m} x$ $3 \mathrm{~m} \times 3 \mathrm{~m}$. All of its facades have several layers of insulation. This platform was designed to test materials and construction systems under the Mexico City microclimate. It is possible to measure thermal, lighting, acoustic and indoor air quality variables. Mexico City building codes indicate that the minimum span to be used in a room must be at least $17.5 \%$ of the area of the room. Using the Experimentation Façade, which allows us to observe all available orientations; we place a window with these characteristics and measure its thermal behavior in each of the orientations. The results obtained allowed us to identify that the window when observing the North or South orientations does not greatly increase the internal temperature of the Module. On the other hand, when the window observes the orientations East and West, the internal temperature increase, establishes conditions of inhabitability inside the Module, recording temperatures of above $50^{\circ} \mathrm{C}$.
\end{abstract}

Keywords: Thermal Behavior, Heat Transfer, Glazing heat gain, Full Scale Testing Module.

\section{Introduction}

Mexico City has a subtropical highland climate with mild winter and warm summer as well as small seasonal variations in temperature. Despite this, effort towards reducing energy consumption to provide indoor thermal comfort need to be continued especially through passive means. Previous studies have proven that selecting good envelope material is an important strategy to reduce heat gain and heat loss in a building depending on the outdoor conditions. (Garay Roberto, 2014) (Kopp, 2012) (Nassif, 2014).

As part of the technical benefits, the Master and $\mathrm{PhD}$ Program in Architecture of the National Autonomous University of Mexico has a Full Scale Testing platform integrated by two Full Scale Testing Modules (FSTM) located in the roof of the Post-Graduate building.

On this experimental space, whose operation and thermal conditions are met, research on how heat wave affects the internal temperature of the envelope, as well as the interior temperature of the FSTM are conducted.

At the beginning of this research characterization of the thermal behaviour of the FSTM is conducted which proposes to study the effects on the internal thermal load that produces a window in its different orientations. According to the building codes of Mexico
City, the minimum window to be observed for a room corresponds to $17.5 \%$ of its floor area, i.e. the area in elevation of the window cannot be less than this percentage $(17.5 \%)$ of the surface of the room.

This window is located at the "Experimental façade" and is composed of 15 slots, which change its original configuration of blind wall to a $6 \mathrm{~mm}$ thick clear glass window with the aim of reaching the desired $17.5 \%$, in order to analyse its performance and how it affects the internal temperature of the module as well as the cavity behaviour of the double skin envelope.

To reach temperature stability inside the test module, the measured outdoor meteorological data was analysed and compared with those obtained inside the Full-Scale Testing Module. This study focusses on evaluating the behaviour of the double skin envelope and how the window and its orientation modify the internal conditions.

Each module could rotate $360^{\circ}$, so that the "Experimental Façade" can observe different orientations with the aim that this façade or any other could see any orientation for a certain time throughout the year.

This paper presents the results obtained so far on the thermal behaviour of the envelope. 


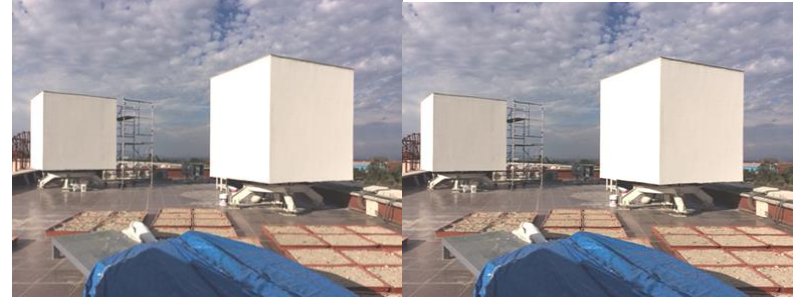

Fig. 1.Full Scale Testing Modules.

Thus the aim of this study is to measure and to know the thermal conditions inside the FSTM and also inside the cavity of the double skin envelope, when opening a minimum window according to the Building Codes in México. The data obtained in 2016 when the envelope was completely sealed is compared with those obtained in the same period of 2017. Measurements at different orientations were analysed and the thermal effects on the interior was established.

It is important to note that the double skin envelope is composed of several layers of thermal insulation; Table 1 presents the " $U$ " for each component of the FSTM.

Table 1: "U" Values of the envelope components for the system

\begin{tabular}{|c|c|c|c|c|c|}
\hline \multirow{2}{*}{ Description } & Thickness & $\begin{array}{c}\text { Mean } \\
\text { Density }\end{array}$ & $\begin{array}{l}\text { "K" value } \\
\text { Mean }\end{array}$ & $\begin{array}{c}\text { Thermal } \\
\text { Resistance }\end{array}$ & "U" Value \\
\hline & (m) & $(\mathrm{Kg} / \mathrm{m} 3)$ & $\left(\mathrm{W} / \mathrm{m} 2^{\circ} \mathrm{K}\right)$ & $R=$ thicknes $s / k$ & $U=1 / \sum R$ \\
\hline \begin{tabular}{|r|} 
Vertical Double Skin Envelope Area (m2) \\
10.24
\end{tabular} & 0.3044 & 662.85 & 0.19 & 8.256 & 0.11916 \\
\hline \begin{tabular}{|l} 
Experimental Facade Blind Area $(\mathrm{m} 2)$ \\
4.935
\end{tabular} & 0.32 & 661.34 & 0.25 & 9.317 & 0.10578 \\
\hline \begin{tabular}{|r|} 
Experimental Facade $17.5 \%$ window Area ( $\mathrm{m} 2)$ \\
0.625 \\
\end{tabular} & 0.006 & 2500 & 1.16 & 0.005 & 193.3333 \\
\hline Bottom Area (m2) & 0.22 & 444.70 & 0.13 & 6.037 & 0.16328 \\
\hline Cover Area (m2) & 0.36 & 568.12 & 0.17 & 10.629 & 0.09331 \\
\hline
\end{tabular}

\section{Method}

Instruments that measure meteorological variables on the outside were installed and was used as a reference for comparison with measurements obtained inside. HOBO U-30 and Vaisala WXT 520 weather stations was used and the data was recorded every minute. The variables recorded were outdoor air temperature, relative humidity, barometric pressure, wind, rainfall and Global Radiation.

Inside the modules, the air temperature, Relative Humidity, Mean Radiant Temperature (MRT) were measured while inside the cavity of the double skin façade, surface thermistor was used to measure the inner layer envelope temp. Table 2 shows the equipment installed.

Figure 2 shows the equipment (Globe Thermometer, Hobo U12, and Campbell 107 Probe) installed inside the testing module. It shows the inner layer of insulation where the surfaces are covered by insulation in order to avoid heat gain or losses. Over the blind wall all the panel joints are filled, in order to prevent gain or losses by infiltration. On the other hand the interior temperature of the glazing on the Experimental Facade was also measured with a surface thermistor.

Table 2: Installed Equipment

\begin{tabular}{|l|l|l|l|l|l|}
\hline & Equipment & Trademark & Model & Parameter & Unit \\
\hline & Multisensor & HOBO & U-12 & $\begin{array}{l}\text { Air Tempera- } \\
\text { ture }\end{array}$ & ${ }^{\circ} \mathrm{C}$ \\
\cline { 4 - 6 } & & & $\begin{array}{l}\text { Relative } \\
\text { Humidity }\end{array}$ & $\%$ \\
& & & & Humidi & \\
\hline
\end{tabular}

\begin{tabular}{|l|l|l|l|l|l|}
\hline $\begin{array}{l}\text { Temperature } \\
\text { Probe }\end{array}$ & $\begin{array}{l}\text { Campbell } \\
\text { Scientific }\end{array}$ & 107 & $\begin{array}{l}\text { Air Tempera- } \\
\text { ture }\end{array}$ & ${ }^{\circ} \mathrm{C}$ \\
\cline { 2 - 6 } & $\begin{array}{l}\text { Surface Mount } \\
\text { Thermistor }\end{array}$ & $\begin{array}{l}\text { Campbell } \\
\text { Scientific }\end{array}$ & $\begin{array}{l}110 \\
\text { PV }\end{array}$ & $\begin{array}{l}\text { Surface } \\
\text { Temperature }\end{array}$ & ${ }^{\circ} \mathrm{C}$ \\
\hline $\begin{array}{l}\text { Type "E" } \\
\text { Thermistor. }\end{array}$ & $\begin{array}{l}\text { Campbell } \\
\text { Scientific }\end{array}$ & $\begin{array}{l}\text { Type } \\
\text { E }\end{array}$ & $\begin{array}{l}\text { Mean Radi- } \\
\text { ant Tempera- } \\
\text { ture }\end{array}$ & ${ }^{\circ} \mathrm{C}$ \\
$\begin{array}{l}\text { Inside Globe } \\
\text { Thermometer. }\end{array}$ & & & & \\
\hline $\begin{array}{l}\text { Data Acquisi- } \\
\text { tion System }\end{array}$ & Campbell & CR- & - & - \\
\hline
\end{tabular}

Fig. 2. Equipment installed inside the FSTM.
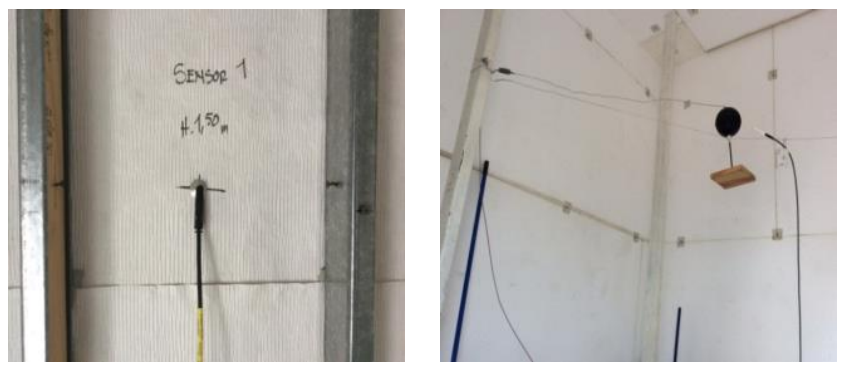

\section{Results and Discussion}

The results field measurements from June 1 to July 31, 2016 are shown, in order to compare those obtained in the same period of 2017 with the Experimental Façade modified. The end of spring and the beginning of summer is the warmest time in Mexico City. Temperature data of the inner surface of the envelope cavity as well as the MRT were measured inside the FSTM.

Focus of measurements was made for the warmest time of the year, between the months of June and July. Data were recorded every minute. Figure 3 shows the conditions observed during June and July of 2016, showing maximum, minimum and average values of each of the variables (external temperature and MRT inside the module) as well as the internal temperature of the cavity in each of the façade that received energy from the sun. The maximum temperature reached outside was $31.10^{\circ} \mathrm{C}$, and the average for the period was $18.07^{\circ} \mathrm{C}$. The MRT maximum data was $23.69^{\circ} \mathrm{C}$ while the average was $19.26^{\circ} \mathrm{C}$. In this graph the average of every variable was from $20.17^{\circ} \mathrm{C}$ to $18.39^{\circ} \mathrm{C}$. As can be seen in the graph, the differences between the outside temperature and the MRT speaks of the insulating efficiency of the envelope.

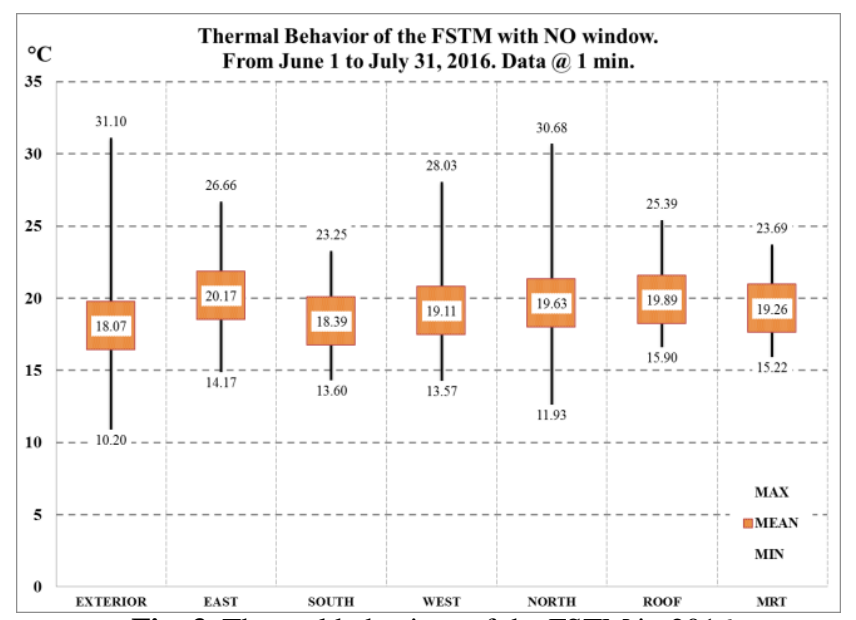

Fig. 3. Thermal behaviour of the FSTM in 2016. 
During the measurements made in 2017 with the glazing placed, measurements were taken orienting the window to the four cardinal points, one week at a time. It must be indicated that for all the periods of 2017, the same scale is used in the graphs, in order to make them comparable to each other. Figure 4 shows the results obtained with the window towards the North orientation, in the

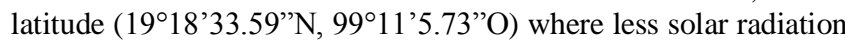
is received, the average temperature values are very close to each other. The maximum exterior temperature was $29.10^{\circ} \mathrm{C}$ and the average during the period was $16.91^{\circ} \mathrm{C}$ while on the MRT, maximum data was $26.90^{\circ} \mathrm{C}$ and the average was $20.62^{\circ} \mathrm{C}$ implying that Roof, East, South and North façades show values which are close to each other. The West façade has the highest measurement with $25^{\circ} \mathrm{C}$ as the maximum temperature and $18.77^{\circ} \mathrm{C}$ as average.

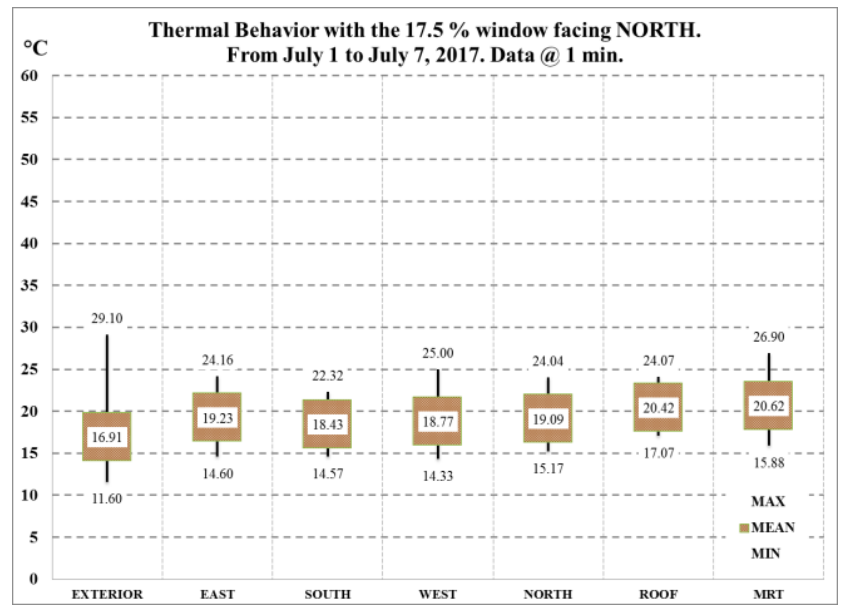

Fig. 4. Thermal behaviour with window facing North.

Figure 5 shows the behaviour presented with the window facing South. A slight increase in data is recorded, but still not significant in the interior temperature. The exterior has a maximum of $30.30^{\circ} \mathrm{C}$ and an average of $18.12^{\circ} \mathrm{C}$. The MRT registered a maximum of $28.49^{\circ} \mathrm{C}$ and an average of $21.74^{\circ} \mathrm{C}$. With these results it can be argued that the glazing in the south façade causes a slight raise in the internal temperature of the FSTM

Figure 6 presents the data obtained with the window facing East. From these observations, the internal temperature condition is found to change significantly. While the outside temperature observes a maximum of $30.40^{\circ} \mathrm{C}$ and an average of $19.75^{\circ} \mathrm{C}$, the MRT has a maximum of $43.3^{\circ} \mathrm{C}$ and an average of $26.03^{\circ} \mathrm{C}$, which indicates that it makes the space inhabitable due to the overheating gained during the morning.

Figure 7 shows the behaviour obtained with the window facing West with heat gain towards the interior for this orientation being the highest recorded. While the outdoor conditions recorded a maximum temperature of $31.50^{\circ} \mathrm{C}$ and an average of $21.16^{\circ} \mathrm{C}$, the MRT reaches a maximum of $55.24^{\circ} \mathrm{C}$ and an average of $26.63^{\circ} \mathrm{C}$ well above the permitted thermal habitability conditions, from 20 $25^{\circ} \mathrm{C}$ in accordance with ISO-7730-2005 "Ergonomics of the thermal environment" (Standardization, 2005). It is evident that with this kind of glazing in this orientation an overheating of the interior is achieved.

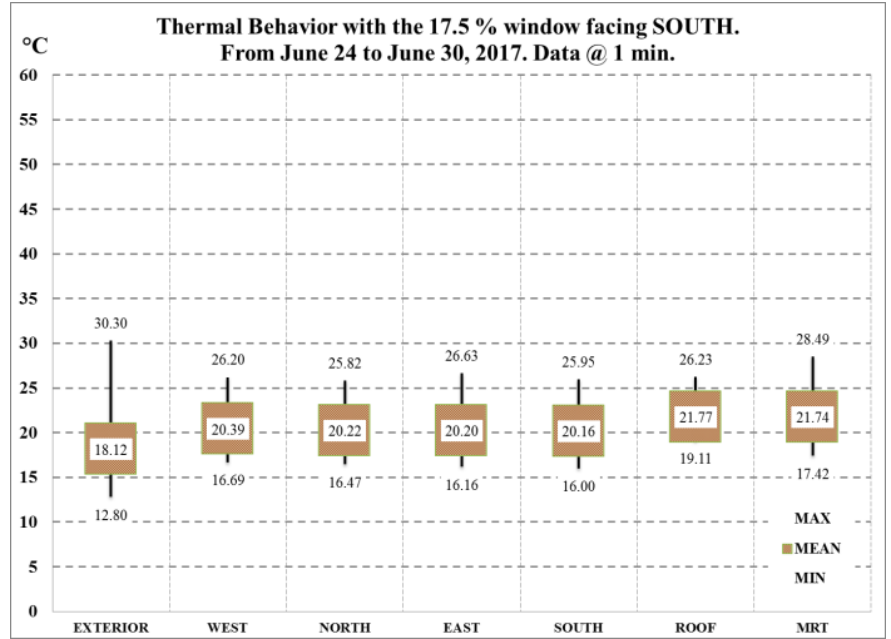

Fig. 5. Thermal behaviour with the window facing South.

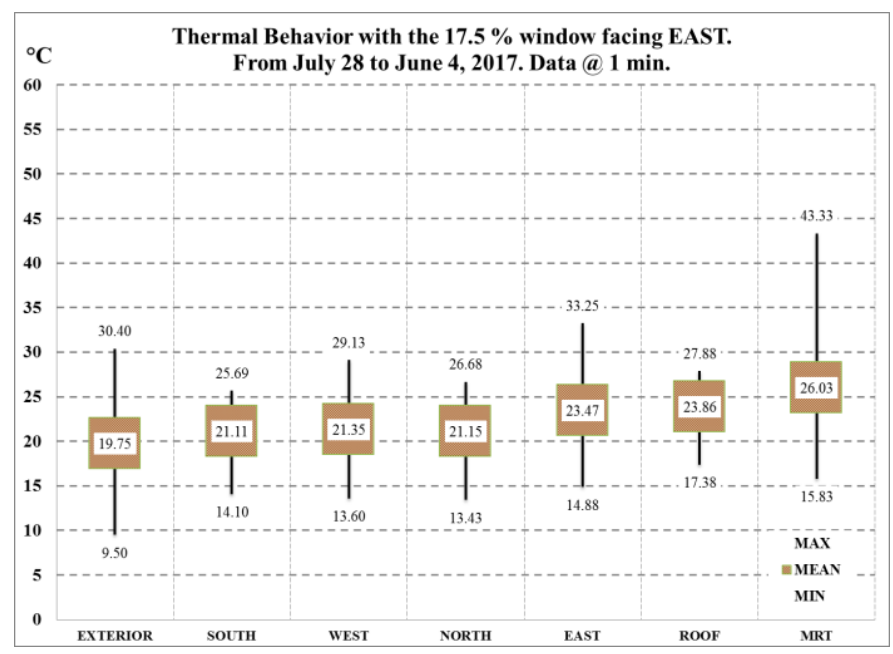

Fig. 6. Thermal behaviour with the window facing East.

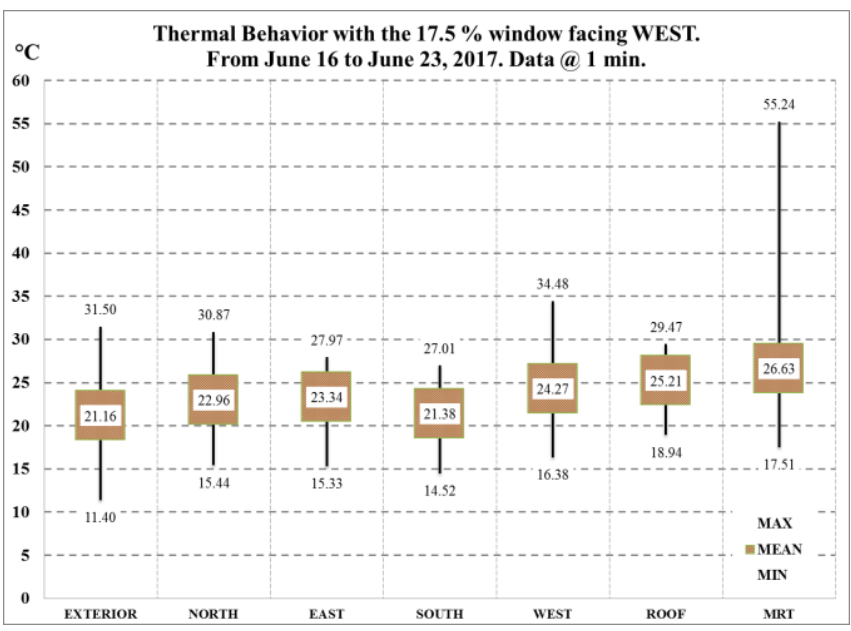

Fig. 7.Thermal behaviour with the window facing West.5.

\section{Conclusion}

The study verified the operation and insulating effectiveness of the FSTM envelope, achieving a temperature gradient for the MRT of less than $5^{\circ} \mathrm{C}$ during the months of May and June, the warmest in Mexico. 
The building codes indicate that the ratio of the minimum window for a room is $17.5 \%$ relative to its floor area. Using this ratio, the thermal behaviour of both the interior of the FSTM and the cavity of the double skin envelope was analysed and compared with those recorded in the Exterior Temperature.

It can be concluded that glazing increases the internal temperature depending on the orientation. For the North and South façades, the increases registered in relation to the measurements obtained with the blind façade on 2016, are to a certain extent lower and do not seriously affect the temperature inside the FSTM.

On the other hand, the temperature data recorded in the East and West façades show a significant increase on the internal conditions of the FSTM. The east and west façades receive enough sunning to make the module uninhabitable. It is noted that the maximum temperatures recorded in the MRT sensor were $43.33^{\circ} \mathrm{C}$ and $55.24^{\circ} \mathrm{C}$. The averages in both orientations were always kept above $26^{\circ} \mathrm{C}$.

It can be argued that the gain and loss of heat through the proposed $17.5 \%$ glazing, modify the stability of conditions achieved with the closed envelope in 2016. In the latitude studied, it is necessary to study the orientations in depth and before proposing glazed spans, solar protection must be provided as a configuration and specification of glass necessary to reduce the overheating through the window.

\section{Acknowledgement}

This project was founded by CONACYT National Council of Science and Technology of Mexico and The National Autonomous University of Mexico (UNAM). Additional funding was provided by the Ministry of Higher Education, Malaysia under the Exploratory Research Grant Scheme (ERGS 5/3 45/2013). We also would like to thank to the Master and Ph.D. Program in Architecture, and the Environmental Interaction Laboratory (LIM) which facilitate the use of the building and equipment to carry out this research.

\section{References}

[1] Author," 2015-2, P. C. (2015). Final Document, Complementary Practice. Sem. 2015-2. PMDA. Mexico City. Master Program in Architecture, UNAM

[2] Allen, W. (1997). Envelope Design for Buildings, Architectural Press, London.

[3] Asdrubali, F., D’Alessandro, F., Baldinelli, G. Evaluating in situ thermal transmittance of green buildings masonries - A case study. (2014). Case Studies in Construction Materials 1 (2014) 53-59.

[4] Berg, B. (2009). The Ecology of Building Materials. 2nd edition Routledge, Oxford

[5] Boake, T. M. (2003). Understanding the General Principles of the Double Façade System. University of Waterloo, 1-18. http://www.tboake.com/pdf/double_facade_general.pdf

[6] Boake, T. M. (2014). Hot climate Double Facades: Avoiding Solar Gain. Façade Tectonics Journal. 14 http://www.tboake.com/bio/facadetectonics2014boake-rev.pdf

[7] Crespo, L. A. (2004). History of The Double Skin Facade. Harvard University.

[8] Flexlab (2016). The world's Most Advanced Building Efficiency Test Bed. https://flexlab.lbl.gov

[9] Garay, R., Uriarte, A., Apraiz, I. (2014). Performance assessment of thermal bridge elements into a full scale experimental study of a building facade. Energy and Buildings 85 (2014) 579-591.

[10] Kopp, G., Morrison, M., Henderson, D. (2012) Full-scale testing of low rise, residential buildings with realistic wind loads. Journal of
Wind Engineering and Industrial Aerodynamics 104-106 (2012) 25-39.

[11] Nassif, A., Yoshitake, I., Allam, A. Full-scale fire testing and numerical modelling of the transient thermos-mechanical behavior of steel-stud gypsum board partition walls. Construction and Building Materials 59 (2014) 51-61.

[12] Shameri, M. A., Alghoul, M. A., Sopian, K., Zain, M. F. M., \& Elayeb, O. (2011). Perspectives of double skin façade systems in buildings and energy saving. Renewable and Sustainable Energy Reviews, 15(3), 1468-1475.

[13] Standardization, I. O. (2005). ISO-7730-2005. USA: ISO.

[14] Tecnalia (2016). Infrastructure and Equipment: Kubic by Tecnalia http://www.tecnalia.com/es/construccionsostenible/infraestructuras-equipamiento/infraestructurasequipamiento.htm 